ACTA MYCOLOGICA

Vol. 41 (2): 169-176

2006
Dedicated to Professor Alina Skirgietto

on the occasion of her ninety fifth birthday

\title{
The genus Echinostelium (Myxomycetes) in Lithuania
}

\author{
GRAŽINA ADAMONYTE் \\ Laboratory of Mycology, Institute of Botany \\ Žaliụjų Ežerų 49, LT 08406 Vilnius, grazina@botanika.lt
}

Adamonytè G.: The genus Echinostelium (Myxomycetes) in Lithuania. Acta Mycol. 41 (2): 169 176, 2006.

Seven species of the genus Echinostelium apitectum, E. arboreum, E. brooksii, E. colliculosum, E. corynophorum, E. aff. elachiston, E. minutum are reported from Lithuania. Their morphological peculiarities are discussed; a key to the species, pictures and distribution maps are given.

Key words: myxomycetes, acellular slime molds, moist chamber cultures, morphology, ecology, distribution

\section{INTRODUCTION}

The genus Echinostelium de Bary was erected in Rostafiński (1873) for myxomycetes with very pale spores and stipitate minute sporocarps that rarely exceed 500 $\mu \mathrm{m}$. Myxomycetes of the genus mostly inhabit bark of living trees and shrubs but can also be occasionaly found on litter including tiny branchlets or coniferous needles. Their sporocarps are especially fragile and usually short-living, therefore they are seldom collected in the field. Thus, for investigations of this group simple but highly efficient techniques of substrate incubation in the laboratory is very useful. So far 16 species have been described within the genus. One of them, E. vanderpoellii Nann.-Bremek., D. W. Mitch., T. N. Lakh. et R. K. Chopra, later was proposed to reduce to a synonym of E. apitectum K. D. Whitney (Pando 1997). Another one, Echinostelium roseum Ing, was excluded because it appeared to be not a myxomycete (Ing 1984). In Lithuania the first records of Echinostelium species were obtained in late 1990'ies; up to now 7 species are known from the country: Echinostelium apitectum, E. arboreum, E. brooksii, E. colliculosum, E. corynophorum, E. aff. elachiston, E. minutum. All these species except for E. minutum are reported here for the first time for Lithuania. The paper also presents morphological, ecological and geographical data on Lithuanian Echinostelium species. 


\section{MATERIAL AND METHODS}

Virtually all Echinostelium specimens described here were obtained from moist chamber cultures. Whit n ey (1980) proposed a special protocol for revealing Echinostelium species; it includes substrate soaking for 1-3 hours, and further incubation in the dark at $12-15^{\circ} \mathrm{C}$. In the present research the cultures were processed following Härkönen (1977) because I aimed to reveal not only Echinostelium, but all myxomycetes which might inhabit a particular substrate. So, bark pieces cut from a living tree/shrub trunk or main branches were placed in one layer into Petri dishes lined with filter paper. The dishes were filled with distilled water and left closed for $24 \mathrm{hrs}$ at room temperature in a natural light regime, then excess water was poured out. The dishes closed with covers were further kept in room temperature in a natural light regime and regularly checked for myxomycete sporocarps - on the first incubation week daily, later on once a week. Emerged sporocarps were allowed to dry slowly by slightly opening a lid and leaving for a night. Echinostelium species usually developed within first few days, but sometimes additional mass sporifications of $E$. minutum were observed after a considerable time.

Microscopic examination was carried out in fresh preparations in 3\% KOH. Micrographs of sporocarps stained with Cotton Blue were made with a Pentax *istDS camera mounted on a Biolam-I microscope. Scanning electron micrographs were made from air-fresh material with Hitachi S2500 SEM at the Natural History Museum, London. Voucher specimens of the species are kept in the herbarium of the Institute of Botany, Vilnius (BILAS).

Bark $\mathrm{pH}$ was measured with IQ-150 $\mathrm{pH}$-meter with ThermoRussel flat-head electrode KDCEF11 on the second day after water was removed.

Nomenclature of myxomycetes follows La do (2001). Standard forms of authors' names are according to Brummitt and Powell (1992).

\section{SPECIES DESCRIPTIONS AND DISCUSSION}

Echinostelium apitectum K. D. Whitney, Mycologia 72 (5): 954 (1980), Fig. 1, 2, 3, 4.

Sporocarps gregarious, rosy when fresh, later turning whitish, 120-300 $\mu \mathrm{m}$ high; stalk hyaline in transmitted light (TL), partly filled with a refuse material; sporotheca 40-70 $\mu \mathrm{m}$ diam., spores closely packed together; peridium persisting as a basal collar covering up to $1 / 3$ of a spore-like body; spore-like body $8-14 \mu \mathrm{m}$ diam.; columella mostly reduced or inconspicuous; capillitium absent, when present reduced to a short single or forking thread; spores whitish in mass, hyaline in TL, smooth or minutely warted, 6-9.5 $\mu \mathrm{m}$ diam.

Substrates. Bark of Fraxinus excelsior, Picea abies, Pinus sylvestris, Populus sp., Quercus robur, Ulmus sp. Substrate $\mathrm{pH}$ ranges from 3.4 to 6.9.

Distribution. Kèdainiai, Pasvalys, Ukmergè, Jonava, Prienai distr., Vilnius city (Fig. 5). Frequent, more than 80 records.

Notes. Echinostelium apitectum is rather variable species ranging from well-developed columella (bearing threads of capillitium) to strongly reduced or even absent columella. La do and Pando (1997) distinguish two forms of E. apitectum: one with large (10-12 $\mu \mathrm{m}$ diam.) and the second with small (6-9 $\mu \mathrm{m}$ diam.) spores, sporocarps of the latter also being taller and more slender. But the authors admit that 


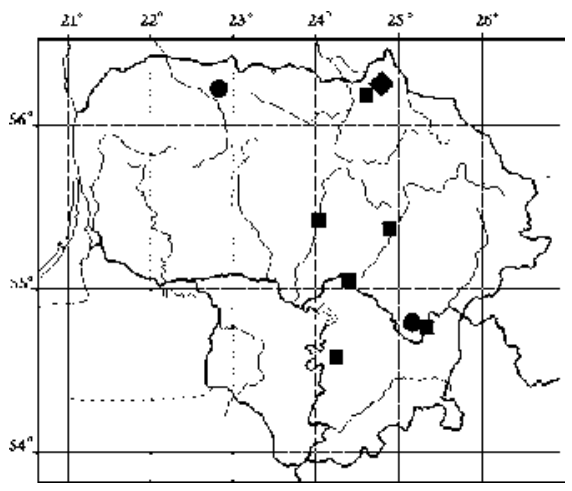

Fig. 5. Localities of E. apitectum (ם), E. colliculosum (৩), and E. aff. elachiston $(\diamond)$ in Lithuania.

both forms merge, and for their taxonomical recognition further evidence would be needed. In the Lithuanian material of E. apitectum two groups can be distinguished, too. One group included stouter sporocarps with no apparent columella, spore-like body reaching 11-14 $\mu \mathrm{m}$ diam., and spores approx. 6-7.5 $\mu \mathrm{m}$ diam., appearing warted under transmitted light (TL, oil immersion). The other one covered higher and more slender sporocarps with a smaller spore-like body (8-10 $\mu \mathrm{m}$ diam.), discernible columella, and slightly larger spores (7.5-8 $\mu \mathrm{m}$ diam.). But, similarly to Lado and Pando (1997) experience, there were also specimens transitional between both groups in the Lithuanian material, therefore all they were ascribed to E. apitectum.

In Lithuania $E$. apitectum was most frequently found on acid substrates: the highest number of collections was obtained from Pinus sylvestris bark which $\mathrm{pH}$ ranged from 3.7 to 4.6 . The myxomycete was also found - albeit only sporadically - on bark of deciduous trees with higher $\mathrm{pH}$ (up to 6.3); one collection was found on bark with nearly neutral $\mathrm{pH}$ reaching 6.9. This experience rather supports results obtained by Wrigley de Basanta (2004): in her model experiments of acid rain simulation E. apitectum sporulated on bark with lower $\mathrm{pH}$ values after treating it with solutions of $\mathrm{pH} 3$ and 4 . However, some authors report that E. apitectum was frequently collected from bark of Juniperus thurifera (Lad o 1993) and Olea europaea (Pando 1989, l. c. Wrigley de Basanta 2000) whose pH is significantly higher - 5.5-6.5.

Echinostelium arboreum H. W. Keller et T. E. Brooks, Mycologia 68: 1207 (1977), Fig. 6.

Sporocarps scattered, sitting on leaf tips of mosses, yellow, 130-150 $\mu \mathrm{m}$ high; stalk yellowish in TL, partly filled with a refuse material; sporotheca 70-80 $\mu \mathrm{m}$ diam.; peridium persistent, shining, when evanescent remains as a colar at the base of columella; capillitium well developed, branching dichotomously up to 3 times, not forming a periferial net; spores hyaline in TL, varted, 8.5-9 $\mu \mathrm{m}$ diam.

SuBSTRATES. Bark of Fraxinus excelsior overgrown with epiphytic mosses Neckera complanata (Biržai distr.) and Leucodon sciuroides (Ukmergè distr.). pH 5.8.

Distribution. Biržai, Ukmergè distr. (Fig. 7). Rare, 3 records.

NotEs. Species is easily recognizable by bright-yellow short-stalked sporocarps with shining peridium and abundant capillitium.

In both localities, bark for moist chamber cultures was collected in biologically rich forests. In Biržai district it was collected in the Botanical Reserve of Biržai For- 


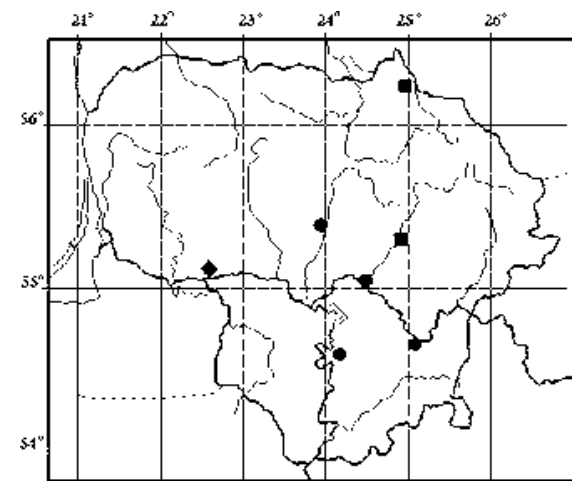

Fig. 7. Localities of E. arboreum ( $\mathbf{\square})$, E. brooksii $(\bullet)$, and E. corynophorum ( $\bullet$ in Lithuania.

est, in Ukmergè district bark was taken in a broad-leaved forest with Quercus robur ca 150 years-old.

Echinostelium brooksii K. D. Whitney, Mycologia 72 (5): 957 (1980), Fig. 8.

Sporocarps gregarious, rosy when fresh, turning pale brown, $100-150 \mu \mathrm{m}$ high; stalk hyaline in TL, partly filled with a refuse material; sporotheca 40-60 $\mu \mathrm{m}$ diam., spores loosely packed in the sporotheca; peridium evanescent, remaining as a small colar at the base of columella; columella hemispherical on a short stalk, brown, 4.5$6.5 \mu \mathrm{m}$ diam.; spores rosy in mass, pale rosy in TL, appearing smooth, with a thinner germination area, 10.5-14 $\mu \mathrm{m}$ diam.

Substrates. Bark of Picea abies, Pinus sylvestris, occasionally Fraxinus excelsior. Substrate $\mathrm{pH}$ ranges from 3.4 to 5.7.

Distribution. Jonava, Kèdainiai, Prienai, Trakai distr. (Fig. 7). Frequent, more than 75 records.

Notes. Echinostelium brooksii is close to E. corynophorum; for differences columella and spores should be examined (see comments under E. corynophorum).

E. brooksii most frequently occurred on bark of Pinus sylvestris, together with Echinostelium apitectum and E. minutum. E. brooksii sporulated with the highest frequency on bark whose $\mathrm{pH}$ range was the same as for E. apitectum - from 3.7 to 4.6, but its general $\mathrm{pH}$ range was narrower: only a few collections were obtained from bark which $\mathrm{pH}$ was more than 5.0. So, this species appears to be confined to the most acid substrates among species of the g. Echinostelium.

Echinostelium colliculosum K. D. Whitney et H. W. Keller, Mycologia 72: 641 (1980), Fig. 9, 10, 11.

Sporocarps gregarious, whitish, 70-120 $\mu \mathrm{m}$ high; stalk hyaline in TL, partly filled with a refuse material; sporotheca $30-40 \mu \mathrm{m}$ diam.; peridium persisting as a colar; spore-like body with thickened areas, $8.5-9 \mu \mathrm{m}$ diam.; spores hyaline in TL, minutely warted, bearing circular thickened areas, 8-9.5 $\mu \mathrm{m}$ diam.

SuBSTRATE. Bark of Fraxinus excelsior. pH 6.6-7.5.

Distribution. Akmenè distr., Vilnius city (Fig. 5). Rare, 4 records.

Notes. Echinostelium colliculosum is characterized by small sporocarps and thickened articular areas on the spore wall. From a very closely related species E. coelocephalum T. E. Brooks et H. W. Keller (which have not been registered in Lithuania, so far) it is said to differ in larger spores with less pronounced thickened areas, as 
well as in the colar form (Whitney, Keller 1980). Thus, in E. colliculosum collar is larger and its margins adhere to the spore-like body, while in E. coelocephalum collar margins appear to stay free. In specimens which are described here the colar was large, and its margins were attached closely to the spore-like body. But even under oil-immersion it was difficult to discern whether thickened areas on a spore-like body and spore walls were of the uniform thickeness (E. coelocephalum) or tapering towards edges (E. colliculosum). As the critical drying point technique was not applied while preparing material for SEM examination, these thickenings were not distinct in SEM photographs, too.

In Lithuania E. colliculosum was observed on bark of trees growing along roadsides; $\mathrm{pH}$ of the bark cultures was close to neutral. Bearing in mind that in western Kazakhstan steppe $E$. colliculosum was also collected from windbreak-forming trees with bark $\mathrm{pH}$ as high as 7.2-8.4 (unpublished data), it appears that this species prefers substrata with neutral to slightly alkaline reaction.

Echinostelium corynophorum K. D. Whitney, Mycologia 72: 963 (1980), Fig. 12.

Sporocarps gregarious, white, up to $100 \mu \mathrm{m}$ high; stalk hyaline in TL, partly filled with a refuse material; sporotheca ca. $30 \mu \mathrm{m}$ diam.; peridium remaining as a small colar at the base of columella; spore-like body absent; columella subglobose, on a short stalk, light brown, 3-3.5 $\mu \mathrm{m}$ diam., 3.5-4 $\mu \mathrm{m}$ high; spores hyaline in TL, with thickened areas, $11.5-12 \mu \mathrm{m}$ diam.

Substrate. Alnus glutinosa female cones; pH 6.1.

Distribution. Taurage distr. (Fig. 7). Rare, 1 record.

Notes. As noted by Whitney (1980) Echinostelium corynophorum is closely related to $E$. brooksii. The author points at the following differences: columella in $E$. corynophorum is hyaline to pale yellow while in E. brooksii it is always deeply dark; spores of E. corynophorum bear thickenings and are white, meanwhile spores of E. brooksii are smooth and rosy. For distinguishing these two species Lado and Pando (1997) suggest one more particular trait: the thinnest part of E. corynophorum stalk is in a short distance below the collar, and the thinnest section of $E$. brooksii stalk is right below the colar. In the only specimen from Lithuania which is described here the thinnest area of the stalk was not well distinguished, the size of sporotheca and columella were on the smaller end of the scale for the species, but spores bore distinct thickened areas. The shape of columellae of E. brooksii and $E$. corynophorum collected in Lithuania differed markedly: the first was hemispherical, or horizontally lenticular, and the second was subglobose.

Echinostelium aff. elachiston Alexop., Mycologia 50: 52 (1958), Fig. 13.

Sporocarps gregarious, whitish, shining, 100-110 $\mu \mathrm{m}$ high; stalk yellowish in TL, partly filled with a refuse material; sporotheca 30-35 $\mu \mathrm{m}$ diam; peridium hyaline, after evanescing leaving a large collar (ca $15 \mu \mathrm{m}$ ) on the top of stalk; spore-like body absent; columella indiscernible; spores appearing warted (oil-immersion), 8-9.5 $\mu \mathrm{m}$ diam.

SubSTRATE. Bark of Fraxinus excelsior.

Distribution. Biržai distr. (Fig. 5). Rare, 2 records.

Notes. Echinostelium elachiston is characterized by small, yellow tinted sporocarps, a wide collar on the tip of stalk, scanty to absent capillitium, and spores of 6.5-8 $\mu \mathrm{m}$ diam. Martin and Alexopoulos (1969) state that spores of this species 
are smooth with well-marked thickened circular areas on the wall, while Whitney (1980) specifies that they are minutely roughened and lacking circular thickenings. Spores of specimens from Spain described by Lado and Pando (1997) also are said to have smooth wall of uniform thickness, but their measurements reach up to $11 \mu \mathrm{m}$ diam. Warts on spore wall of both available Lithuanian specimens were very conspicuous, particularly when stained with Cotton Blue, and spores were in general larger than it is noted in the species protologue. All other characteristics of these specimens rather well agreed with the concept of E. elachiston.

Substrate $\mathrm{pH}$ was not measured for available specimens of $E$. aff. elachiston, but data show that $\mathrm{pH}$ of bark of Fraxinus excelsior growing in natural conditions is close to 5.5-6 (unpublished data).

Echinostelium minutum de Bary in Rostaf., Śluzowce Monogr.: 215 (1874), Fig. 14.

Sporocarps gregarious, white or pale rosy, 250-500 $\mu \mathrm{m}$ high; stalk hyaline in TL, partly filled with a refuse material; sporotheca $50 \mu \mathrm{m}$ diam.; peridium evanescent, remaining as a small colar at the base of columella; spore-like body absent; columella light brown, ca $4 \mu \mathrm{m}$ high; capillitium well developed, never forming a net, consisting of a few threads, usually one or two of them being long and dichotomously branched; spores hyaline or pale rosy, 6.5-14 $\mu \mathrm{m}$ diam.

SubStRATEs. Bark of Alnus glutinosa, Betula sp., Fraxinus excelsior, Juniperus communis, Picea abies, Pinus sylvestris, Populus tremula, Quercus robur; occasionally litter: female cones of Alnus glutinosa, mixed litter of leaves, fine branchlets and needles; once excrements of herbivores (moose). Substrate pH ranges from 3.4 to 6.9.

Distribution. Biržai, Jonava, Kèdainiai, Lazdijai, Prienai, Radviliškis, Šalčininkai, Tauragè, Trakai, Ukmergè, Varèna distr., Neringa city (Fig. 15). Common, more than 120 records.

Notes. Small sporocarps of Echinostelium minutum with scanty capillitium can resemble E. apitectum, however the latter species has a spore-like body.

E. minutum is the most common species of the genus recorded in almost all regions of Lithuania where myxomycetes were investigated. Its sporocarps readily appeared in moist chamber cultures on a great variety of substrata with a wide range of $\mathrm{pH}$ from highly acidic to nearly neutral. But most frequently its sporification was observed at $\mathrm{pH}$ 3.4-6.1. If the cultures were kept for sufficiently long time, additional waves of $E$. minutum sporification occured. E. g, in a culture of moose dung sporocarps of this species were noted 3 months after setting the culture, then the

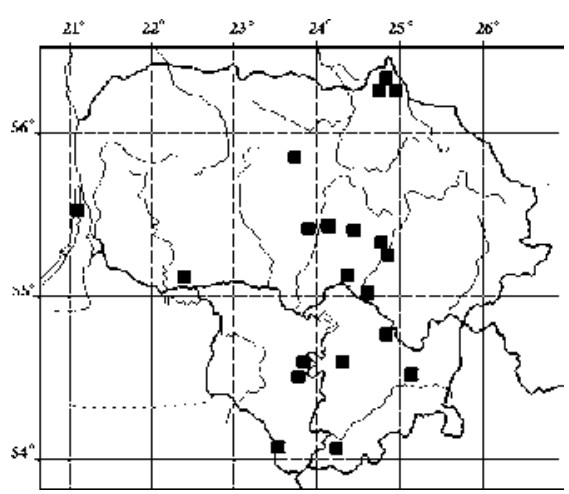

Fig. 15. Localities of Echinostelium minu tum (ם) in Lithuania. 
next sporification occurred three and a half months after the first sporification. One more sporification took place 10 months after setting the culture, but sporocarps were scanty. This phenomenon was not observed for other Echinostelium species, although it was noted for Physarum viride (Bull.) Pers. var. aurantium (Bull.) Lister, Arcyria cinerea (Bull.) Pers., and Paradiacheopsis fimbriata (G. Lister et Cran) Hertel (Dvořáková 2002).

\section{KEY TO THE GENUS ECHINOSTELIUM LITHUANIA}

1. Capillitium present 2

- Capillitium absent

2. Capillitium well developed, spore-like body absent

- Capillitium scanty, spore-like body present

E. apitectum

3. Sporocarps long-stalked, white or rosy E. minutum

3. Sporocarps short-stalked, yellow E. arboreum

4. Spore-like body present 5

- Spore-like body absent 6

5. Spore wall with circular thickenings E. colliculosum

- Spore wall without circular thickenings E. apitectum

6. Columella present 7

- Columella absent E. elachiston

7. Columella dark, spore wall without circular thickenings E. brooksii

- Columela pale, spore wall with circular thickenings E. corynophorum

Acknowledgements: This paper is dedicated to an outstanding Polish mycologist Professor Alina Skir giełł. I much appreciate help of Dr. Carlos Lado at determination of a specimen of Echinostelium apitec tum. Thanks are due to Dr. Ernestas Kutorga for discussions during preparation of the paper, and to Dr. Ilona Jukoniene for identification of mosses. This study was supported in part by the Lithuanian Studies and Science Foundation (grants No G 139, G 169, T 79/05). Access to SEM and Photomicrography and Light Microscopy facilities at the Natural History Museum, London, was granted by the EC funded IHP Programme SYS Resource. Many thanks are extended to Mr. Chris Jones for introducing me SEM techniques.

\section{REFERENCES}

Brummitt R. K., Powell C. E. 1992. Authors of plant names. Kew.

Dvořáková R. 2002. Myxomycetes in Bohemian Karst and Hřebeny Mts. Czech Mycol. 53 (4): 319 349.

Härkönen M. 1977. Corticolous Myxomycetes in three different habitats in southern Finland. Karstenia 17: 1932.

Ing B. 1984. On the identity of Echinostelium roseum B. Ing (Myxomycetes). Trans. Br. Mycol. Soc. 82: 173.

Lado C. 1993. Myxomycetes of mediterranean woodlands. (In:) D. N. Pegler, L. Boddy, B. In g, P. M. Kirk (eds). Fungi of Europe: Investigation, Recording and Conservation. Royal Bo tanical Gardens, Kew: 93114.

Lad o C. 2001. Nomenmyx. A nomenclatural taxabase of myxomycetes. Real Jardín Botánico (CSIC), Madrid.

La do C., Pand o F. 1997. Myxomycetes, I. Ceratiomyxales, Echinosteliales, Liceales, Trichiales. Real Jardín Botánico (CSIC) \& J. Cramer, Madrid, Berlin, Stuttgart.

Martin G. W., Alaxopoulos C. J. 1969. The myxomycetes. University of Iowa Press, Iowa City. 
Pand o F. 1997. A new species and a synonymy in Echinostelium (Myxomycetes). Mycotaxon 64: 343 348.

Rostafiński J. T. 1873. Versuch eines Systems der Mycetozoen. Strassburg.

Whitney K. D. 1980. The myxomycete genus Echinostelium. Mycologia 72: 950987.

Whitney K. D., Kelle r H. W. 1980. A new species of Echinostelium. Mycologia 72: 640643.

Wrigley de Basanta D. 2000. Acid deposition in Madrid and corticolous myxomycetes. Stapfia 73, zugleich Kataloge des OÖ. Landesmuseums Neue Folge 155: 113120.

Wrigley de Basanta D. 2004. The effect of simulated acid rain on corticolous myxomycetes. Syst. Geogr. Pl. 74: 175181.

\section{Rodzaj Echinostelium (Myxomycetes) na Litwie}

\section{Streszczenie}

$\mathrm{Na}$ Litwie stwierdzono dotychczas występowanie siedmiu gatunków z rodzaju Echinoste lium: E. apitectum, E. arboreum, E. brooksii, E. colliculosum, E. corynophorum, E. aff. elachi ston i E. minutum. Praca zawiera klucz do oznaczania gatunków, krytyczną analizę cech mor fologicznych oraz dane o substracie i rozmieszczeniu poszczególnych gatunków z wykazaniem stanowisk na mapie Litwy. 